\title{
Adaptation of Asma'ul Husna in Existing Design Practice
}

\author{
Nor Ziratul Aqma Norzaman ${ }^{1 *}$, Khairul Aidil Azlin Abd Rahman², Mohd Yazid \\ Mohd Yunos' ${ }^{3}$ and Nor 'Atiah Ismail ${ }^{3}$ \\ ${ }^{1}$ Department of Industrial Design, Faculty of Innovative Design \& Technology, Universiti Sultan Zainal Abidin, \\ Kuala Terengganu, 21300, Malaysia \\ ${ }^{2}$ Department of Industrial Design Faculty of Design and Architecture, Universiti Putra Malaysia, Serdang, \\ 43400, Malaysia \\ ${ }^{3}$ Department of Landscape Architecture, Faculty of Design and Architecture, Universiti Putra Malaysia, \\ Serdang, 43400, Malaysia
}

\begin{abstract}
Until now, industrial designers are solely educated with the epistemology of dialectical materialism; meanwhile, the spiritual aspect is often segregated from education affairs. Many kinds of literature highlighted that this segregation could lead to negative impacts. Supposedly as a Muslim, learning about our Creator through Asma'ul Husna is an essential trait to develop designers' value, also known as sahsiah or characteristic of excellence. Therefore, this paper attempted to study the adaptation of Asma'ul Husna in the existing design practice among Muslim designers and at the same time devote the existent designer's knowledge and awareness to this understanding. A set of questionnaires were distributed using stratified sampling. The result showed that the majority of the respondents did not adapt Asma'ul Husna in the existing design practice due to limited knowledge on ways to integrate Asma 'ul Husna in the design process. Designers who claimed to use Asma'ul Husna in design are either still confused with the usage or only limits the usage to motif and zikr. As an overview, this paper highlights the general view of an adaptation of Asma 'ul Husna's among designers and emphasises the urgency to develop a guideline for designers to implement the values in their design process.
\end{abstract}

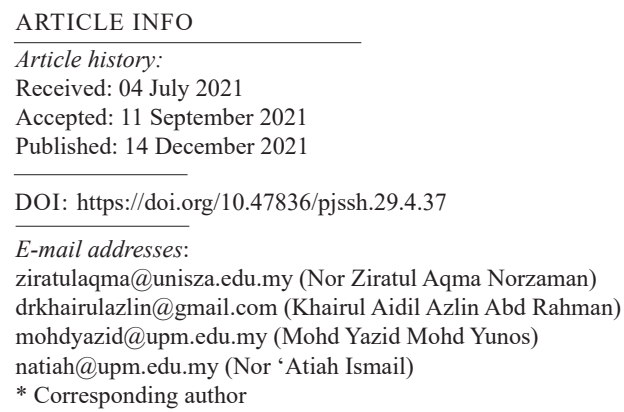

Keywords: Asma'ul husna in designing, industrial design, industrial design curriculum, secularism

\section{INTRODUCTION}

Gardiner and Rothwell (1985), Hicks (2014), Tovey (1997), World Design Organisation (2017), Yliris and Buur (2007) and Cuffaro et al. (2013) define industrial designer as 
an individual who practises professionally, applied secular design process in producing good design product through fulfilling human wants and need focussing on profit maximisation.

Therefore, it is understandable that a designer should learn the concept of customer preference (perceptions toward evaluation of good design product) to improve profits. In relation to design education, according to Lawson (2005) and Liu (1991), since then, industrial designers must equip themselves with the epistemology of dialectical materialism, various kinds of knowledge and undergo training in designing school with various practices in order to educate, cultivate and improve the quality of the designer's work.

It is terrifying to discover that implicitly, designers are being taught to encourage consumers to seek and establish worldly paradise through materializing in consumption. As being pointed out by Richins and Dawson, the Oxford English Dictionary refer to materialism as "a devotion to material needs and desire, to the neglect of spiritual matter; a way of life, opinion or tendency based entirely upon material interests" (1992, p. 891).

As pointed out by Saeed et al. (2001), for an instant, encouraging customers to pursue satisfaction through materials will turn them into the slaves of the marketing firms. Ramadan (2011) did remind; an autonomous Muslim should not be a slave of material but a servant of God. However, unfortunately, as Abdul Razzaq Naufal (1982) highlighted, the pleasure and joy that humans find in this world gradually pull them away from Allah.

Referring to Aydin (2013), when the existing design curriculum focuses on profit maximisation and materialism aspect, it is contradicting with Islamic teachings, and Norzaman et al. (2018) considered the secular design approach as incomplete because it only covered duniawi and left no option for designers to prioritise consumer over Allah. It refers to intention (nawaitu) niat) of designer while designing. In Islam based on Alserhan (2010), all actions are judged by their intention behind their action, thus this includes design practice.

Walker (2013) added and clarified that, contemporary design practice limits spirituality solely to the individual's private domain. Hence, resulting it to becomes a less important aspect in education, professional practices, public decision making. Not only that, history also showed that obtaining materialism, modernity, advancement, sophistication will inevitably be accompanied by degradation of the natural environment or in other word, pollution and unsustainability.

Whereas according to Aydin (2013) and Sheikh Munawar Haque (2021), Allah purposely creates human as caliphs (Allah's vicegerent) as the best mankind amongst all and His other creations in this universe to facilitate and be responsible in managing the world. Even in the Quran, Allah repeatedly reminded humans to abstain from practising corruption in this world.

"You are indeed the best community that has ever been brought forth for 
(the good of) mankind. You enjoin what is good and forbid what is evil and you believe in Allah. If only people of the Scripture had believed, it would have surely been better for them. Among them are true believers, but most of them are defiantly disobedient." (The Quran, 2012, 3:110)

'When they are told,' Do not cause corruption in the land, they say; "we are only promoters of peace, but it is they who are really causing corruption though they do not realize it." (The Quran, 2012, 2:1112)

"Eat and drink what God has provided and do not act wrongfully in the land, spreading corruption" (The Quran, 2012, 2:60)

"Do not defraud people of what is rightfully theirs and do not spread corruption in the land" (The Quran, 2012, 26:183)

In addition, according to Noor Fazreena and Mohd Zuhdi (2015) today's education structure is based on dualism system that poses multiple worldview, couples with different values and beliefs to a point it isolates divinity element in the modern sciences.

To further highlight the problem with the existing design curriculum, Noor Fazreena and Mohd Zuhdi (2015) mentioned that today's education structure is based on dualism system that poses multiple worldview, couples with different values and beliefs to a point it isolates divinity element in the modern sciences. Isolating the spiritual or divinity element could lead to a negative impact because we believe Islam is the way of life. Based on E1Bassiouny (2014) and Zarabozo (2009), Islam covers tauhid, iman, ibadah, Sharia law and the most important part is way of live to humanity.

Supposedly, according to Halstead (2004), useful concept of knowledge based on Muslim perspective is able to help users acknowledge God, live in accordance to Islamic Law and fulfil the purpose of God's creation. Therefore, it is really important to integrate the divinity element which is through Asma'ul Husna into the existing design process and re-orientate the designer's design process.

Briefly, Haque and Keshavarzi (2014) define Asma'ul Husna as the beautiful names of Allah and Murtadho (2012), Zakaria and Mat Akhir (2017) explained that Asma'ul Husna consist of 99 names of Allah and El-bassiouny (2016) classified them as Divine attributes.

According to Ali (2006), Asma'ul Husna embodies the concept of tauhid that is described as the consciousness of the oneness of Allah. It is the only source of knowledge that could save humanity and foster excellent ummah as mentioned in The Quran,

"Remember Allah abundantly, in order that you become successful."

(The Quran, 2012, 8:45) 


\section{Designer as Khalifah}

With the idea of tauhid, a designer must strive to reorient every action and move towards Allah or Asma'ul Husna especially in their design practise. Even Muslim (2018) agree that, there is a lack of exploration in linking the design process with Asma'ul Husna. Hence, this study intends to look on the existing design approach used especially among the Muslim designers. The main question is, do the designers ever use Asma 'ul Husna in the design process?

Abd Rahman (2005) also highlighted in Table 1, example of design courses needed to be learned by a designer in relation to knowledge conversion process. He classified designer model into four types: designer as imitator, designer as apprentice, designer as a collaborator and designer as thinker.

In Islam, we do have another type of designer; designer as Khalifah. Designer as khalifah is a mediator between consumer, Allah, and organisation. In integrating this idea into the conventional design process, the integration of Asma'ul Husna should embark at early part of the design process which is within the industrial designer.

Figure 1 visualises the idea in integrating Asma'ul Husna into conventional design process in relation to knowledge conversion process. As the vicegerent (khalifah) of Allah on earth, the believers are advised to implement Asma'ul Husna in every aspect of their life and this is considered as the greatest deed as mentioned in the Quran

"The remembrance of Allah (swt) is the greatest." (The Quran, 2012, 29:45)

Apart from that, El-Bassiouny (2014) also highlighted that maintaining good consciousness by remembering Asma'ul Husna is the main purpose of our life and it can be considered as a form of worship to Allah. Designers who integrate Asma'ul Husna in their design process will have a

Table 1

Design pedagogy

\begin{tabular}{|c|c|c|c|c|}
\hline $\begin{array}{l}\text { Designer } \\
\text { model }\end{array}$ & $\begin{array}{l}\text { Knowledge } \\
\text { conversion process }\end{array}$ & Learning goals & $\begin{array}{l}\text { Design studio/ } \\
\text { Lab activities }\end{array}$ & Examples \\
\hline $\begin{array}{l}\text { Designer as } \\
\text { Imitator }\end{array}$ & $\begin{array}{l}\text { Integration } \\
\text { Explicit to Explicit }\end{array}$ & $\begin{array}{l}\text { Acquisition of know- } \\
\text { what }\end{array}$ & $\begin{array}{l}\text { Learning by doing, } \\
\text { practice, exercise, } \\
\text { repetitions }\end{array}$ & $\begin{array}{l}\text { Workshop, CAD } \\
\text { training, drawing }\end{array}$ \\
\hline $\begin{array}{l}\text { Designer as } \\
\text { Apprentice }\end{array}$ & $\begin{array}{l}\text { Assimilation } \\
\text { Explicit to Tacit }\end{array}$ & $\begin{array}{l}\text { Acquisition of know- } \\
\text { how }\end{array}$ & $\begin{array}{l}\text { Book, magazines, } \\
\text { lectures, factual and } \\
\text { principles }\end{array}$ & $\begin{array}{l}\text { Design Principles, } \\
\text { history, } \\
\text { manufacturing } \\
\text { process }\end{array}$ \\
\hline $\begin{array}{l}\text { Designer as } \\
\text { Collaborator }\end{array}$ & $\begin{array}{l}\text { Reciprocation } \\
\text { Tacit to Tacit }\end{array}$ & $\begin{array}{l}\text { Collaboration } \\
\text { and negotiation, } \\
\text { management know- } \\
\text { why }\end{array}$ & $\begin{array}{l}\text { Discussion groups, } \\
\text { reciprocal learning, } \\
\text { management }\end{array}$ & $\begin{array}{l}\text { Field research, } \\
\text { interaction with } \\
\text { user and producer, } \\
\text { industrial training }\end{array}$ \\
\hline $\begin{array}{l}\text { Designer as } \\
\text { Thinker }\end{array}$ & $\begin{array}{l}\text { Exteriorization } \\
\text { Tacit to Explicit }\end{array}$ & $\begin{array}{l}\text { Critical and reflective } \\
\text { thinking for } \\
\text { innovation, care-why }\end{array}$ & $\begin{array}{l}\text { Discovery learning, } \\
\text { management }\end{array}$ & $\begin{array}{l}\text { Degree project, } \\
\text { experiments, design } \\
\text { competition }\end{array}$ \\
\hline
\end{tabular}




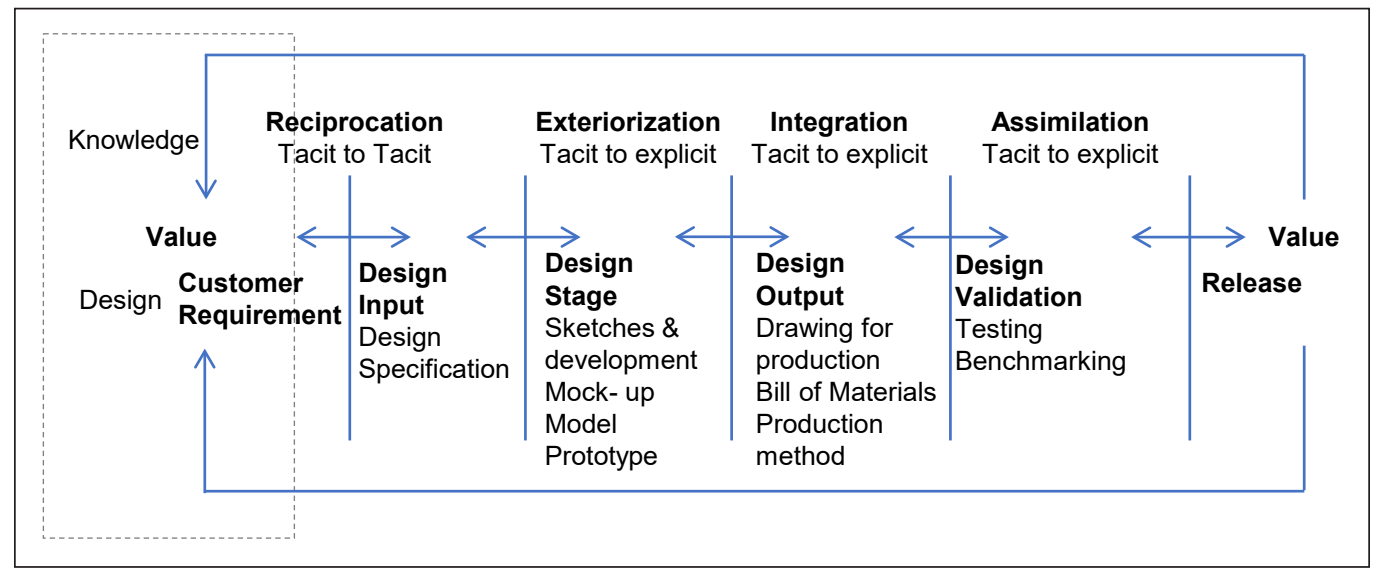

Figure 1. Integration of Asma'ul Husna into ISO 9001 design process

more wholesome approach as they are not only satisfying the consumers' demands but doing it purposefully with good niat. Therefore, as pointed out by Lundgren (2017), it's really important to have special attention in the design process since, a good design process will guarantee a good result. This is further emphasized by Norzaman et al. (2017), who mentioned that an excellent design process will not only please humans, but also please Allah and ultimately helps a person serve the purpose of life.

\section{Benefit of Reorienting Designers' Designing Practice towards Allah}

Assimilating spiritual element into design process is not something impossible. Other religion also did have their own interpretation of religious belief into design. For example, Vasstu Shahstra assimilation of an ancient Indian architecture knowledge with ancient Hinduism; Vedic (Patra, 2009), Zen interpretation of Buddhism (Walker, 2013) and not to mention Feng Shui originally from Chinese belief $(\mathrm{Ng}$, 2016). From Islamic perspective, Asma'ul
Husna relatively a new concept in design which is yet to be thoroughly explore.

The best way to integrate is through Asma'ul Husna since it embodies concept of tauhid. Omer (2020) defined tauhid as the concept of monotheism and opined that understanding the concept is crucial as it also gives a unique identity to Islamic civilization and able to binds all constituents together, making them integral, harmonious and supportive to each other to serve ontological purposes.

Furthermore, Murtadho (2012) also mentioned that, prophets also encourage us to imitate the moral attributes of Allah as reflected in Asma'ul Husna and apply in real life. Not only that, Ahmet and Akdogan (2012) believe that having faith in Allah able in providing inner peace and satisfaction in both worlds.

Shuhari and Hamat (2017) highlighted the importance of understanding Asma'ul Husna among Muslim designer which is clearly indicate in hadith of the prophet and proven have significant benefits to individual where appreciation of Asma'ul 
Husna able to develop characteristic of Trustworthiness (Amanah).

Not only that, Shuhari and Hamat (2011) also agree that understanding Asma'ul Husna is an important value in order to be caliphs in this world. In addition, according to Hamat and Shuhari (2010), understanding Asma'ul Husna is a basic requirement in achieving makrifatullah and developing individual characteristic (for example AlSidq) to become insan robbani (Shuhari, 2020).

Furthermore, Rosmani and Zakaria (2018) highlighted lack of understanding and appreciation toward the Asma'ul Husna value will eventually effect their favourability in learning Islam and effect their faith towards Allah since they unable to feel and see the greatness of Allah. Therefore, the effort in integrating Asma'ul Husna into conventional design process should not be neglected as the integration in the design practice is believed to be beneficial for mankind.

Shuhari et al. (2019) stated that education plays a vital role in building character or personality and an important step in projecting man as a role model in doing good. Integrating Asma'ul Husna into design curriculum is not possible since producing student with holistic personalities through Islamic integrated curriculum is the common vision of Malaysian university, such as in International Islamic University Malaysia (IIUM), Islamic Science University Malaysia (USIM), Islamic Academy of Science (ASASI) as well as Universiti Sultan Zainal Abidin (UniSZA,
Rahimah et al., 2015; Kamal Hassan, 2009; Rahimah et al., 2016).

Thus, it is important to make sure design education today is able to nurture and develop excellent design characteristic aligned with values of Asma'ul Husna. Inevitably designers will produce design which prioritise spiritual aspects and practice values that pleases Allah. Prior to coming up with the guideline for designers in integrating the Asma'ul Husna values in the design process, a study needs to be carried out to observe the existing practise among Muslim designers.

\section{METHOD}

This paper utilized quantitative approach in collecting the data, which is through survey. In order to find out the usability of Asma'ul Husna in the existing design practice, a survey is distributed among Muslim designers, academician and final year students who have art and design background. 163 samples of respondent are sufficient as the findings are equivalent to achieving $85 \%$ confidence level by RASOFT calculator.

Figure 2 categorises the percentage of respondents based on the survey with $34.4 \%$ of the respondents are designers, $20.2 \%$ are among the design academician and the rest are final year students. Final year students are also included in the survey due to their acquired design knowledge and experience in the real working environment while undergoing industrial training.

Meanwhile, Figure 3 breaks down the respondents' area of specialization. It can 


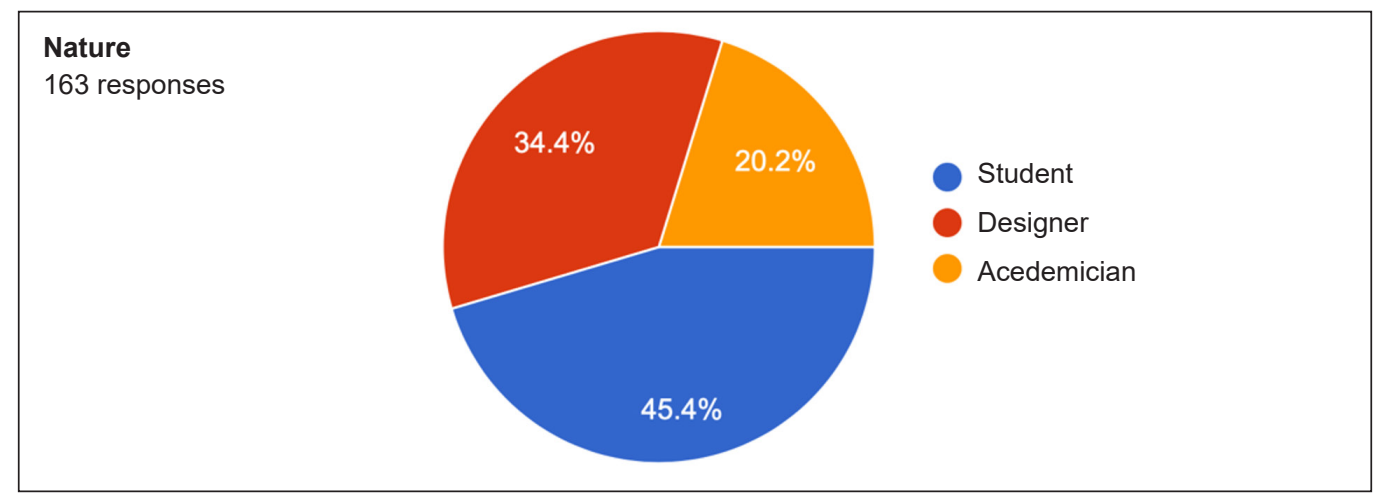

Figure 2. Respondents of the survey

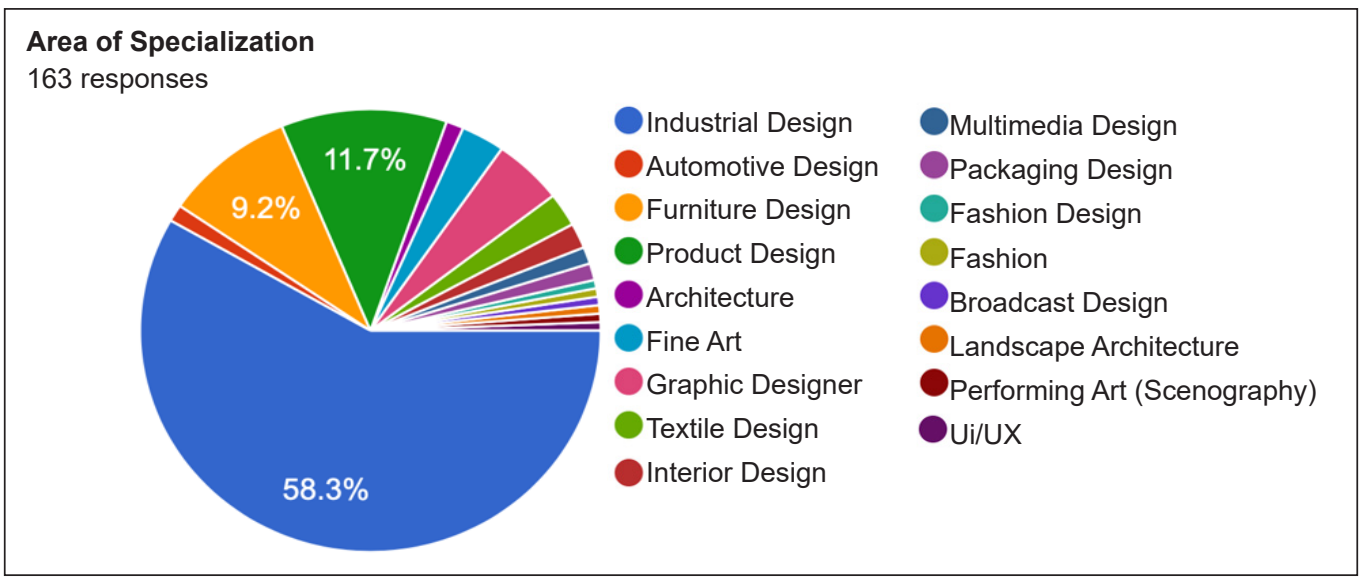

Figure 3. Specialization of respondents

be seen that majority of the respondents are from industrial design which encompasses $58.3 \%$ from the total number of respondents.

\section{RESULTS}

In question 1 , researcher inquired about any respondents who have ever used Asma'ul Husna in their design process. Figure 4 indicates that $87.7 \%$ of them did not use Asma'ul Husna in designing. It is eccentric for a Muslim designer to neglect the use of Asma'ul Husna in a design process as it is mundane to apply the values in daily tasks and while designing. This further rectify the claim that existing design curriculum successfully manage to segregate the spiritual aspect from design practice.

Question 3 probes the reason why majority of them did not use Asma'ul Husna in design (Figure 5). Most of them did not apply Asma'ul Husna in the design process due to limited knowledge on how to use Asma'ul Husna followed by; being afraid to use them since Asma'ul Husna are Allah's sacred names. The rest of them are content with the existing design approach and have little interest to use Asma'ul Husna in design. The finding supports the need 


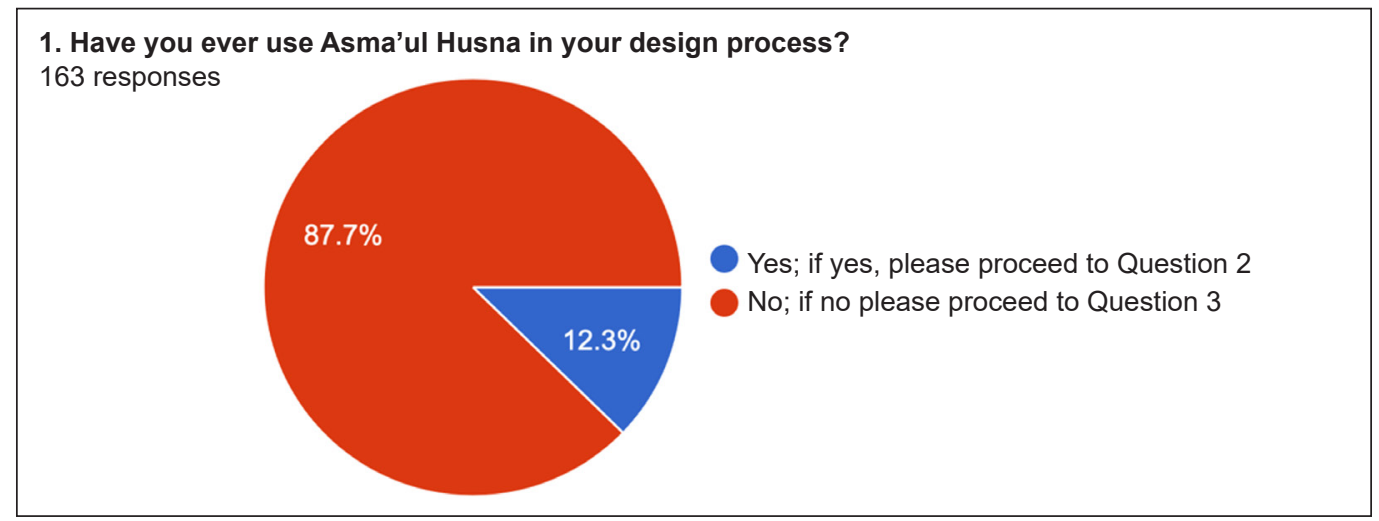

Figure 4. Percentage of respondents who use asma'ul husna in design practise

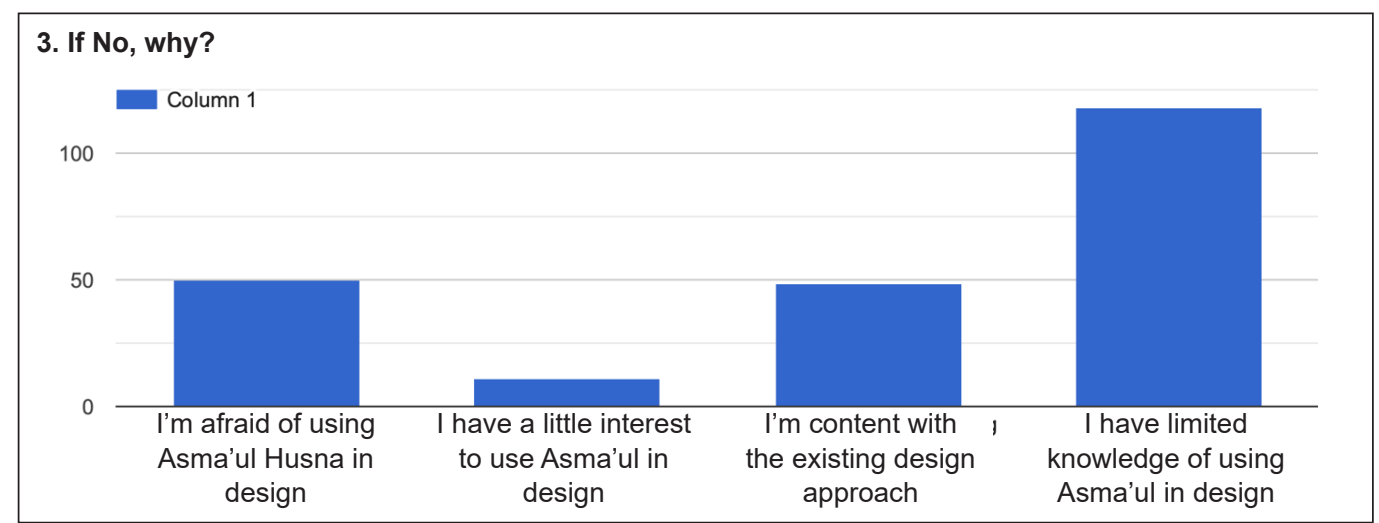

Figure 5. Reason why respondents did not use asma'ul husna in design

in designing proper guideline on how to implement and integrate Asma'ul Husna in the design process.

Furthermore, some of the respondents have a false assumption that the integration of Asma'ul Husna in design practice is not similar to their existing practice (Figure 6). Even in Table 2, R18 point out that integrating Asma'ul Husna in the design process is possible and being practise by them indirectly.

The data in Figure 7 reassured the purpose of this study as it shows a satisfying level of respondents' openness and readiness in integrating Asma'ul Husna in design process. Hence, it is timely to develop a guideline for designers on how to integrate Asma' ul Husna in the design process.

In order to develop the new guideline, Question 2 was curated purposely to understand how designers use Asma'ul Husna in the design process. Although only $12.3 \%$ of the respondents claimed that they use Asma'ul Husna, it still shows the possibility to integrate Asma'ul Husna in the design process. Table 2 explains how they apply Asma'ul Husna in designing.

Analysing the answers in question 2 , it can be deduced that majority of the respondents integrate Asma'ul Husna in 


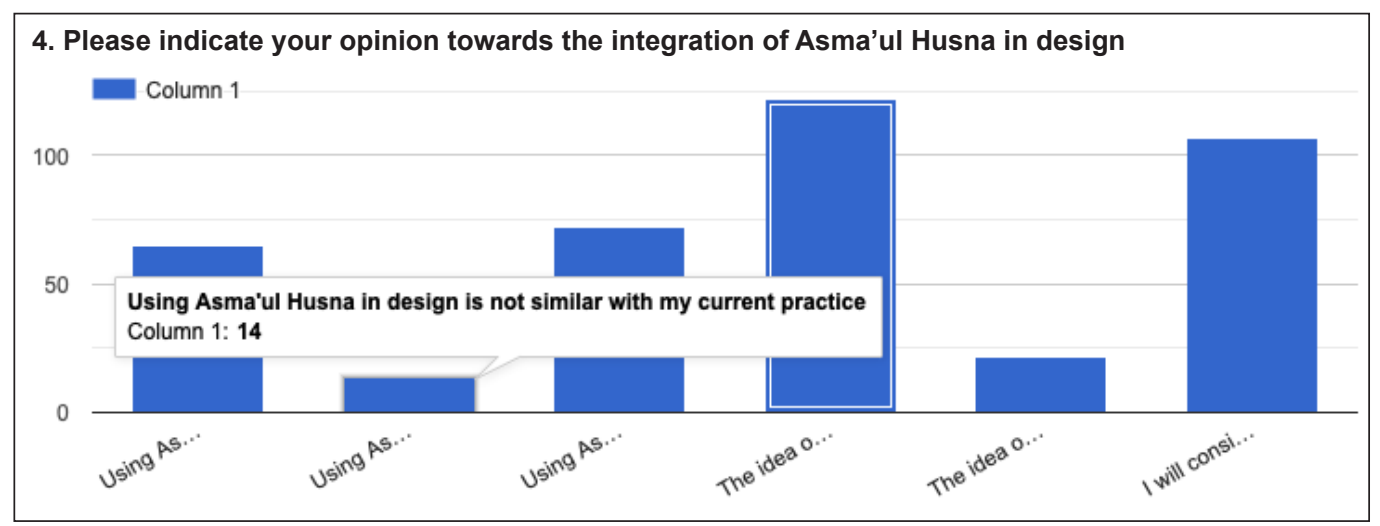

Figure 6. Assumption of respondent that integration of asma'ul husna is not similar with the existing practice

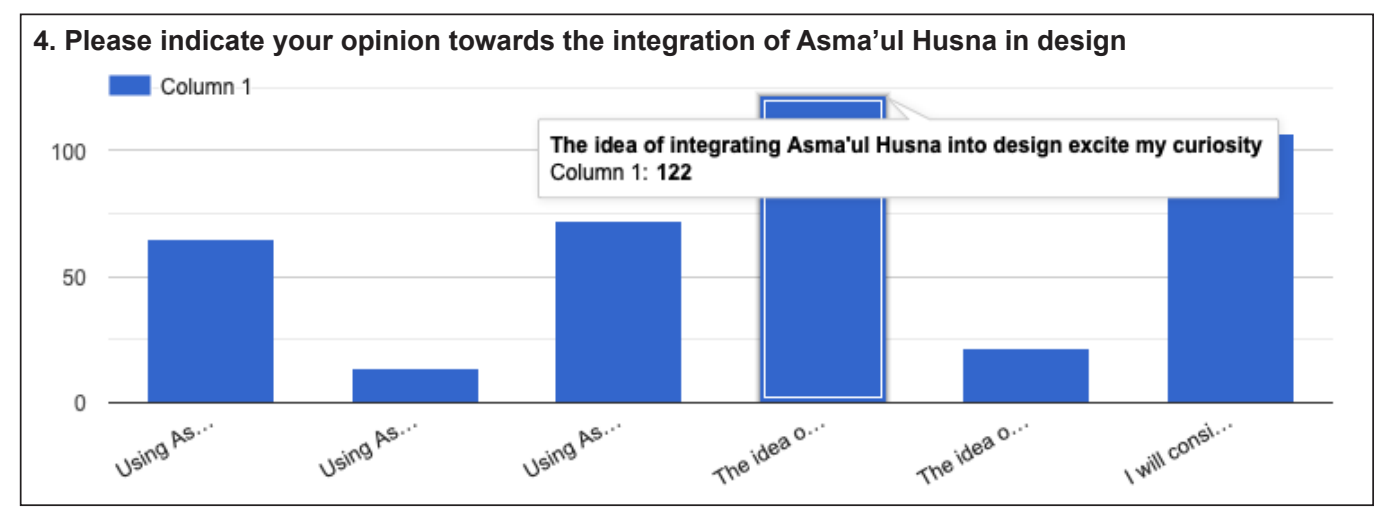

Figure 7. Level of respondents' openness and readiness toward the integration of asma'ul husna in designing

Table 2

How respondents apply Asma'ul Husna in designing

\begin{tabular}{|c|c|c|}
\hline Respondent (R) & Highlighted keyword from the respondents' answer & Category of the keyword \\
\hline R15. & $\begin{array}{l}\text { Use Asma'ul Husna as guideline in every aspect. As } \\
\text { Muslim we should never disregard our creation in } \\
\text { everything, we do }\end{array}$ & $\begin{array}{l}\text { Sharia Compliance, Asma'ul } \\
\text { Husna Value }\end{array}$ \\
\hline R18. & Honest in making any new idea & Asma'ul Husna Value \\
\hline R19. & $\begin{array}{l}\text { Yes, I'm plan for my design on fabric to create the } \\
\text { base on this especially when I started to design on } \\
\text { motif of Islamic design }\end{array}$ & Motif \\
\hline R24. & $\begin{array}{l}\text { Concept \& motif. In fashion design, adhered towards } \\
\text { the aurat guideline is also one of the ways applying } \\
\text { Asma'ul Husna value in design. }\end{array}$ & $\begin{array}{l}\text { Motif, Sharia Compliance, } \\
\text { Asma'ul Husna Value }\end{array}$ \\
\hline R29. & Try to plan project as thorough as possible & Asma'ul Husna Value \\
\hline R35. & $\begin{array}{l}\text { It must reflect the limitations and guidelines in Islam } \\
\text { and sunnah }\end{array}$ & $\begin{array}{l}\text { Sharia Compliance, Asma’ul } \\
\text { Husna Value }\end{array}$ \\
\hline R48. & By giving the best & $\begin{array}{l}\text { Self- Conscious, Asma’ul } \\
\text { Husna Value }\end{array}$ \\
\hline
\end{tabular}


Table 2 (continue)

\begin{tabular}{|c|c|c|}
\hline Respondent (R) & Highlighted keyword from the respondents' answer & Category of the keyword \\
\hline R56. & $\begin{array}{l}\text { For me asma ul husna is not apply in just for design } \\
\text { process. As muslim better apply asma ul husna in all } \\
\text { the thing to get what we want. Cz asma ul husna is } \\
99 \text { names of Allah. In terms of design, we can maybe } \\
\text { recite our dua early with name (ya Hadi) means } \\
\text { giving guidance. Thus, it is more related with the } \\
\text { name of the dua we make. Also, if we had problem in } \\
\text { design we can use as zikr; ya hadi repeatedly to seek } \\
\text { for the guidance. Cz sometimes we get stuck in the } \\
\text { design process. Not just ya hadi...many more name } \\
\text { related we can use, suit with the situation we had. }\end{array}$ & As Zikr \\
\hline R59. & $\begin{array}{l}\text { Asmaul husna in designer's life (esp. Muslim) start } \\
\text { with niat to have a good outcome, during process } \\
\text { development, heart and soul always connected to the } \\
\text { idea (brain) and transferred it into tangible things. } \\
\text { This is how we feel grateful with what ALLAH } \\
\text { given to us. }\end{array}$ & Asma’ul Husna Value \\
\hline R63. & Work with heart, passion and sincerely & Asma'ul Husna Value \\
\hline R70. & $\begin{array}{l}\text { Come out with new design inspired from Allah's } \\
\text { creation }\end{array}$ & Asma’ul Husna Value \\
\hline R71. & $\begin{array}{l}\text { in many ways, such as create the beauty and } \\
\text { ergonomic of design }\end{array}$ & Asma’ul Husna Value \\
\hline R73. & $\begin{array}{l}\text { Being honest in design process, amanah in charging } \\
\text { customer, providing the best design service } \\
\text { regardless design charge. }\end{array}$ & Asma’ul Husna Value \\
\hline R140. & $\begin{array}{l}\text { If I was trusted to do something I would do the best } \\
\text { that I can do since I know Allah Maha Melihat lagi } \\
\text { Maha Mengetahui }\end{array}$ & Asma’ul Husna Value \\
\hline R145. & I'm work in team, and I try my best work with them. & Asma’ul Husna Value \\
\hline $\mathrm{R} 152$. & Always remember Allah every time & Islamic Spirituality \\
\hline R159. & Honest while designing, Allah is All Knowing & Asma'ul Husna Value \\
\hline R161. & $\begin{array}{l}\text { I believe I do, but indirectly. Because as Muslim, it is } \\
\text { ingrained in our practices to practice good deeds in } \\
\text { everything that we do and planned to do. }\end{array}$ & Asma’ul Husna Value \\
\hline R162. & Considering Spiritual values toward design works & Asma’ul Husna Value \\
\hline
\end{tabular}

design process through the values reflected from each name of Allah. Only 3 out of 19 respondents use Asma'ul Husna as zikr and motif in their design artwork. R18 particularly highlighted an interesting answer and the keyword used is 'indirectly'. This indicates that integrating Asma'ul
Husna in design process is possible and had been practised by them subconsciously. By coming up with a well-structured guideline, it will be possible to encourage more designers to integrate Asma'ul Husna in their design process. 


\section{DISCUSSION}

Results from the survey shows that only $12.3 \%$ from the respondents use Asma'ul Husna in design. The remaining respondents did not integrate Asma'ul Husna due to reasons, such as limited knowledge and no proper guideline to be referred to. Findings from this survey also indicates the general view on usability of Asma 'ul Husna and emphasizes the urgency in developing guideline for designers in integrating Asma'ul Husna's values into the design process.

In addition assimilating divinity element especially Integrating Asma'ul Husna values into the design process believed able to improved their faith to Allah and at the same time cultivate good personality according to Islam. Rahimah et al. (2016) also agree that exposing undergrad students with the holistic integrated curriculum able to attain personal's firm belief, accustomed to righteous deed and nurture behavioral skill.

\section{CONCLUSION}

As a conclusion, this study not only intend to look on the adaptation of Asma'ul Husna in existing design practice, it also wants to find out the reason why designer did not use Asma' 'ul Husna and at the same time seek an overall view on existing ways of adapting Asma'ul Husna in the design practice. It is hope that this study to some extend able to create awareness among designer on the possibilities of integrating Asma'ul Husna in their design practice. Finding from this paper also rectify the claim that existing design curriculum successfully manage to segregate the spiritual aspect from design practice and highlights possibilities and needs in developing guideline especially for Muslim designers.

\section{ACKNOWLEDGEMENT}

This study is part of a Fundamental Research Grant from the Ministry of Higher Education (MOHE) with grant number FRGS/1/2016/ SS103/UPM/01/1.

\section{REFERENCES}

Ahmet, N., \& Akdogan, C. (2012). Trust (al-amanah): A comparative study of its application in Islamic and western science. The Asian Conference on Ethics Religion and Philosophy, 47-57.

Ali, M. Y. (2006). Al-tawhid and its effects on man's life. Jurnal Usuluddin, 23, 1-34.

Alserhan, B. A. (2010). On islamic branding: Brands as good deeds. Journal of Islamic Marketing, 1(2), 101-106. https://doi. org/10.1108/17590831011055842

Aydin, N. (2013). Redefining islamic economics as a new economic paradigm. Islamic Economic Studies, 21(1), 1-34. https://doi. org/10.12816/0000238

Cuffaro, D., Blackman C. J., Paige, D., Zacksenberg, I., Laituri, D., \& Covert, D. E. (2013). Industrial design: Reference \& specification book: Everything industrial designers need to know every day. Rockport Publisher.

El-Bassiouny, N. (2014). The one-billionplus marginalization: Toward a scholarly understanding of Islamic consumers. Journal of Business Research, 67(2), 42-49. https://doi. org/10.1016/j.jbusres.2013.03.010

El-Bassiouny, N. (2016). New perspectives on sustainability: Embracing Islamic divine attributes. Journal of Islamic Marketing, (July), $1-7$. 
Gardiner, P., \& Rothwell, R. (1985). Tough customers: Good designs. Design Studies: The Interdisciplinary Journal of Design Research, 6(1), 7-17. https://doi.org/10.1016/0142$694 \mathrm{X}(85) 90036-5$

Abd Rahman, K. A. A. (2005). R\&D for batik: Building creative expert in design. In S. Ab Kareem (Ed.), The business of batik proceedings (pp. 49-55). MPH Group.

Halstead, J. M. (2004). An Islamic concept of education. Comparative Education, 40(4), 517-529. https:// doi.org/10.1080/0305006042000284510

Hamat, M. F., \& Shuhari, M. H. (2010). Al-asma al-husna dalam wacana akidah [Al- Asma Al Husna in the discourse of faith]. AFKAR Journal of Aqidah and Islamic Thought, 11(1), 1-54. http://ajba.um.edu.my/index.php/afkar/article/ view/5796

Haque, A., \& Keshavarzi, H. (2014). Integrating indigenous healing methods in therapy: Muslim beliefs and practices. International Journal of Culture and Mental Health, 7(3), 297-314. https://doi.org/10.1080/17542863.2013.794249

Haque, S. M. (2021). Amanah (trust). https:// docplayer.net/38852652-Amanah-trust-bysheikh-munawar-haque.html

Hicks, J. (2014). Economic theory and the evaluation of consumers' wants. The Journal of Business, 35(3), 256-263.

Kamal Hassan, M. (2009, December 21-23). The mind of islamic intellectuals (ulul-albāb) in accordance with the qura'nic paradigm of intergrated knowledge. Paper presented at Seventh World Conference on Muslim Education, Shah Alam, Malaysia.

Lawson, B. (2005). How designers think: The design process demystifies (4th ed.). Elsevier.

Liu, Z. (1991). The epistemological basis of industrial designing. Design Studies, 12(2), 109-113. https://doi.org/10.1016/0142-694X(91)90053-Y
Lundgren, A. (2017). Why the design process is important. Alvalyn Studio. https://alvalyn.com/ process-and-outcome/

Murtadho, N. (2012). Asmaul husna: Linguistic forms, theological meanings, pedagogical implications, and their equivalents in Indonesian translation. Bahasa dan Seni: Jurnal Bahasa, Sastra, Seni, dan Pengajaran, 40(2), 135-152. http://journal2. um.ac.id/index.php/jbs/article/view/128

Muslim, Z. (2018). Relating design principles with Islamic spirituality based on the transformation of nature in design process. Alam Cipta, 11(2), 44-51. http://spel2.upm.edu.my/webupm/upload/ dokumen/20181224145906artikel_06.pdf

Naufal, A. R. (1982). Mencari keridhaan Allah [Seeking Allah's pleasure] (2nd ed.). Dian Darulnaim Sdn. Bhd.

Ng, Y. L. E. (2016). Urban feng shui: Design guidelines for multifamily residential in Honolulu [Doctoral project, University of Hawai'i]. http:// hdl.handle.net/10125/45578

Noor Fazreena, J., \& Mohd Zuhdi, M. (2015). Sustainability and role of theology: Islamic perspective. Al Qimah Al Mudhafah The Journal of Management and Science (AlQimah), 1(1), 1-10. https:/www.researchgate.net/profile/NoorFazreena-Jusnaidi/publication/303330776_ SUSTAINABILITY_AND_ROLE_OF_ THEOLOGY_ISLAMIC_PERSPECTIVES/ links/573 d436508aea 45 ee 841 ac 41 / SUSTAINABILIT Y-AND-ROLE-OFTHEOLOGY-ISLAMIC-PERSPECTIVES.pdf

Norzaman, N. Z. A., Rahman, K. A. A., Ismail, N., \& Mohd Yunos, M. Y. (2018). Constructing a conceptual framework on integrating the asma ul husna values into the conventional design process. Lecture Notes in Islamic Sciences and Technology, 10-14. https://www. google.com/url? sa $=$ t\&rct $=$ j\&q $=\&$ esrc $=$ s\& s ource $=$ web $\& \mathrm{~cd}=\&$ ved $=2$ ahUKEwiesdqBgf fzAhWj63MBHeBdCL8QFnoECAIQAQ\& 
url $=$ https $\% 3 \mathrm{~A} \% 2 \mathrm{~F} \% 2 \mathrm{Fwww}$. researchgate. net $\% 2$ F publication\%2F 352157487 _ Constructing_a_Conceptual_Framework_on_ Integrating_the_Asma_ul_Husna_Values_into_ the_Conventional_Design_Process\&usg=AOv Vaw0xmJ6v434PwfoMpGaEwbop

Norzaman, N. Z. A., Shaari, N., Abd Rahman, K. A. A., Utaberta, N., \& Jaafar, J. M. (2017). Integrating Asma ul Husna values for design excellence. Pertanika Journal of Social Sciences and Humanities, 25(S), 33-40.

Omer, S. (2020). Tawhid and its implications for Islamic architecture. Journal of Architecture, Planning and Construction Management, 1(2), 21-36. https://journals.iium.edu.my/kaed/index. php/japcm/article/view/465

Patra, R. (2009). Vaastu shastra: Towards sustainable development. Sustainable Development, 17(14), 244-256. https://doi.org/10.1002/sd.388

Rahimah, E., Azhar, Y., Nik Murshidah, N. D., Normila, N. C. A., \& Nur Anis, A. (2015, December 1-2). Module development for enhancing Islamic integrated personality among Muslim students at University Sultan Zainal Abidin. Paper presented at World Islamic Social Science Congress 2015, PICC Putrajaya. http:// eprints.unisza.edu.my/id/eprint/522

Rahimah, E., Nadhirah, N., Abdul Hakim, A., Fadzli, A., Nor Afizan, C. O., \& Rosnani, H. (2016, August 17-19). Analysis of holistic integrated curriculum on contemporary models of higher education institutions in Malaysia. Paper presented at Academic International Conference on Multi-Disciplinary Studies and Education (AICMSE 2016 Oxford), University of Oxford, The Queen's College, Oxford, United Kingdom. http://eprints.unisza.edu.my/id/eprint/976

Ramadan, T. (2011, April 9-10). Islamic education in a pluralistic society: Substance and objectives. Paper presented at the International Conference on Reforms in Islamic Education, Cambridge University, UK.
Richins, M. L., \& Dawson, S. (1992). A consumer values orientation for materialism and its measurement: Scale development and validation. Journal of Consumer Research, 19(3), 303-316. https://doi.org/10.1086/209304

Rosmani, A. F., \& Zakaria, M. H. (2018). Asmaul husna learning through gamifications and adaptation of signalling principle. Journal of Physics, Conference Series: 1st International Conference on Green and Sustainable Computing (ICoGeS) 2017, 1019, Article 012080. https:// doi.org/10.1088/1742-6596/1019/1/012080

Saeed, M., Ahmed, Z. U., Mukhtar, S.-M. (2001). International marketing ethics from an Islamic perspective: A value-maximization approach. Journal of Business Ethics, 32(2), 127-142. https://doi.org/10.1023/A:1010718817155

Shuhari, M. H. (2020). Hubungan al- asma alhusna dengan al- sidq perspektif al- Ghazali berdasarkan al- maqsad al- asna [The relationship of al-asma al-husna with al-sidq from AlGhazali's perspective based on al-maqsad alasna]. Jurnal Akidah \& Pemikiran Islam, 22(1), 35-72.

Shuhari, M. H., \& Hamat, M. F. (2011). Al asma' al husna dan modal insan [Al asma' al husna and human capital]. University of Malaya Press.

Shuhari, M. H., \& Hamat, M. F. (2017). Kefahaman terhadap al-asma' al-husna dan kaitannya dengan ciri al-amanah menurut al-Ghazali dalam kitab al-Maqsad al-Asna [Understanding of al-asma 'al-husna and its relation to the characteristics of al-amanah according to al-Ghazali in the book al-maqsad al-asna]. Malaysian Journal for Islamic Studies, 47-86. https://doi.org/10.22452/ afkar.sp2017no1.2

Shuhari, M. H., Wok Zin, E. I. E., al-Shafi'i, M. M. O., Firdaus, W. M. K., Musa, R., Zin, S. A. M., \& Omar, S. H. S. (2019). An ethical aspect of character building: Ibn Sina's perspective. Journal of Legal, Ethical and Regulatory Issues, 22(1), 1-5. 
The Quran (F. Khanam, Ed. \& M. W. Khan, Trans.). (2012). Goodword Book.

Tovey, M. (1997). Styling and design: Intuition and analysis in industrial design. Design Studies, 18(1), 5-31. https://doi.org/10.1016/S0142694X(96)00006-3

Walker, S. (2013). Design and spirituality: Material culture for a wisdom economy. Design Issues, 29(3), 89-107. https://doi.org/10.1162/ DESI_a_00223

World Design Organisation. (2017). Definition of industrial design. http://wdo.org/about/ definition/
Yliris, S., \& Buur, J. (2007). Designing with video: Focusing the user-centred design process (1st ed.). Springer-Verlag London. https://doi. org/10.1007/978-1-84628-961-3

Zakaria, N., \& Mat Akhir, N. S. (2017). Theories and modules applied in Islamic counseling practices in Malaysia. Journal of Religion and Health, 56(2), 507-520. https://doi.org/10.1007/s10943016-0246-3

Zarabozo, J. D. M. (2009). A guide for the new Muslim. IslamKotob. 